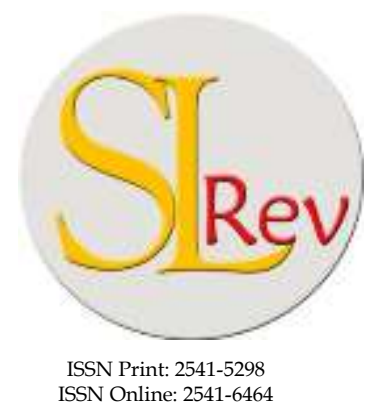

ISSN Online: 2541-6464

\section{SRIWIJAYA}

Editorial Office: Faculty of Law, Sriwijaya University

Jalan Srijaya Negara, Palembang, South Sumatra 30139, Indonesia

Phone: +62711-580063Fax: +62711-581179

E-mail: sriwijayalawreview@unsri.ac.id|sriwijayalawreview@gmail.com

Website: http://journal.fh.unsri.ac.id/index.php/sriwijayalawreview

\title{
Legal Analysis of Current Indonesia's Marine Protected Areas Development
}

\author{
Adrian Nugraha ${ }^{\mathrm{a}}$
}

a Institute of the Law of the Sea, College of Ocean Law and Policy, National Taiwan Ocean University, Taiwan \& Faculty of Law, Sriwijaya University, Indonesia. E-mail: adriannugraha@fh.unsri.ac.id

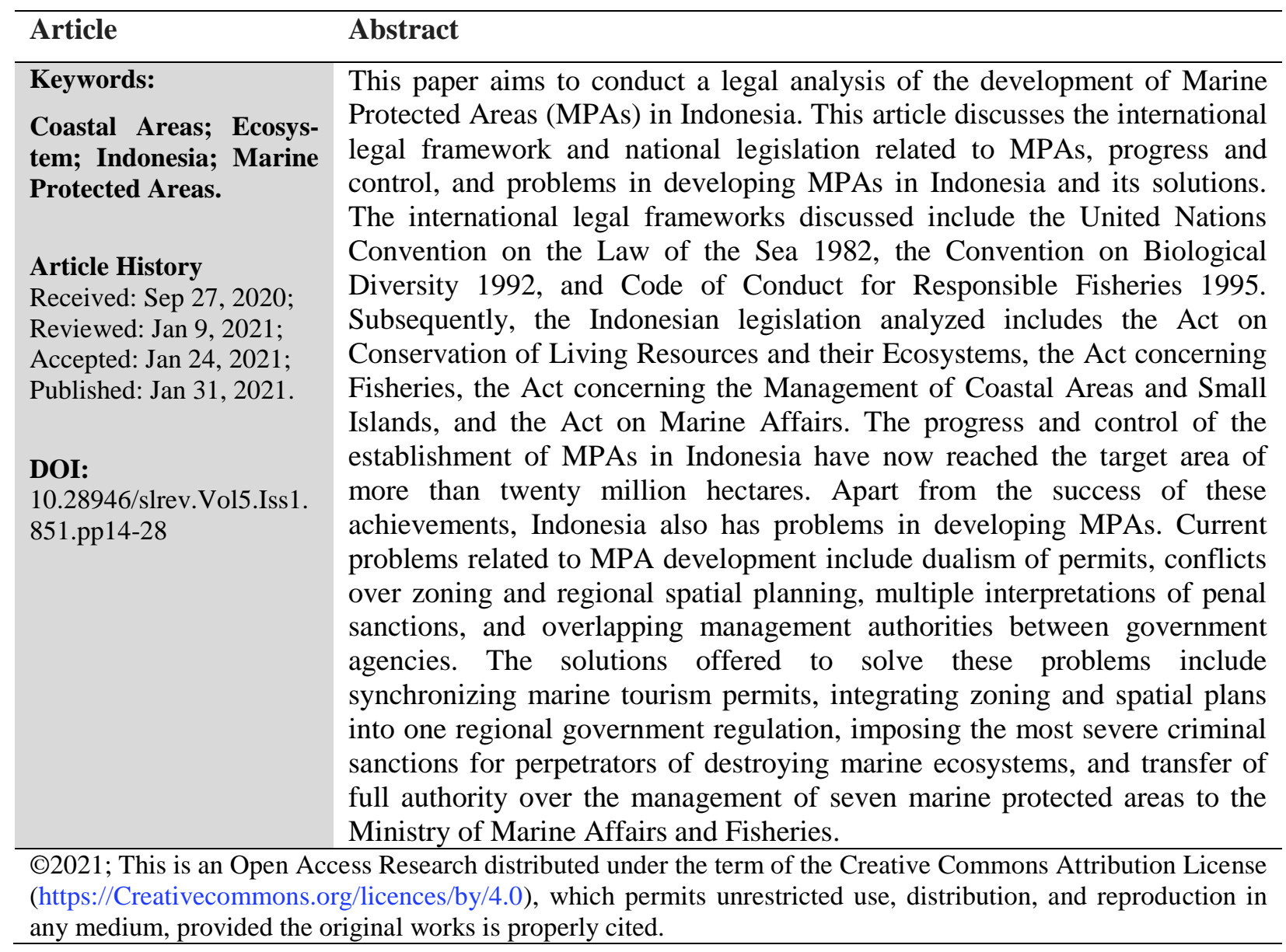

\section{INTRODUCTION}

Consists of 17,500 islands and 99,093 km of coastline, Indonesia is the most significant archipelagic state and has tremendous biodiversity. ${ }^{1}$ The majority of this country's populations are

1 Agus Brotosusilo et al., "Littoral and Coastal Management in Supporting Maritime Security for Realizing Indonesia as World Maritime Axis," IOP Conference Series: Earth and Environmental Science 30, no. 1 (2016). 
inhabiting in the coastal region. Indonesia owns around $27 \%$ of marine fauna and flora in the world. $^{2}$ These species comprise $24 \%$ amphibians, $45 \%$ fish, $39 \%$ molluscs, $8.7 \%$ seaweed, and $13 \%$ of mammals. This diversity of flora and fauna shows that this country is tremendously rich in coastal and marine resources. ${ }^{3}$

Although Indonesia has abundant marine resources, the management of these resources still has several obstacles. Pollution, destructive fisheries, and land areas development are all factors that threaten the marine environment. ${ }^{4}$ Also, sectoral egos in the control of marine and coastal areas among government institutions further worsen marine management's image in Indonesia. $^{5}$

The government has made various efforts to protect marine ecosystems. The establishment of marine protected areas (MPAs) is a significant effort to conserve and protect the marine environment. ${ }^{6}$ MPAs are also considered useful as a robust tool to address menaces to coral reefs and preserve biodiversity, ecosystem services, and habitats. ${ }^{7}$ MPAs may propose the length of protection from the complete exclusion of human activity to lesser forms of limitation. ${ }^{8}$ Various forms of MPAs include fisheries reserves, marine parks, marine sanctuaries, and protected coastal areas. Some scholars believe that proper management of marine protected areas could avoid fish population decline and habitat destruction. ${ }^{9}$

This article discusses a legal analysis related to the current development of marine protected areas in Indonesia. This paper discusses explicitly international legal frameworks and national legislation related to Indonesia's MPAs. Subsequently, this paper also discusses the progress and control of the establishment of MPAs in Indonesia. This article also reveals problems in managing MPAs in Indonesia and provides possible solutions to solve these issues. The problems discussed include dualism of licensing management, zoning conflicts, the imposition of criminal sanctions, and overlapping jurisdictions of government agencies in managing MPAs. Furthermore, the solutions discussed are to overcome these problems, including synchronizing permits, integrating zoning and spatial plans into one local government regulation,

2 Ministry of Marine Affairs and Fisheries, "Annual Report of the Ministry of Marine Affairs and Fisheries Republic of Indonesia 2017” (Jakarta, 2017). (accessed 19 August 2020).

3 Central Bureau of Statistics, "Statistics of Marine and Coastal Resources 2018" (Jakarta, 2018). (accessed 19 August 2020).

4 Evan N. Edinger et al., "Reef Degradation and Coral Biodiversity in Indonesia: Effects of Land-Based Pollution, Destructive Fishing Practices and Changes Over Time," Marine Pollution Bulletin 36, no. 8 (1998): 617-30; Baso Hamdani, "Threats, Challenges and Opportunities to Marine Protected Areas in the Coral Triangle Area: A Case Study of Indonesia Sea.” (Thesis, World Maritime University, 2018), p.35.

5 Daniella Ferrol-Schulte et al., "Coastal Livelihood Vulnerability to Marine Resource Degradation: A Review of the Indonesian National Coastal and Marine Policy Framework," Marine Policy 52, no. 1 (2015): $163-71$.

6 Rafael A. Magris et al., "Integrated Conservation Planning for Coral Reefs: Designing Conservation Zones for Multiple Conservation Objectives in Spatial Prioritisation," Global Ecology and Conservation 11, no. 1 (2017): 53-68, https://doi.org/10.1016/j.gecco.2017.05.002.

7 A. Abelson et al., "Expanding Marine Protected Areas to Include Degraded Coral Reefs," Conservation Biology 30, no. 6 (2016): 1182-91, https://doi.org/10.1111/cobi.12722.

8 Elizabeth M. De Santo, "Missing Marine Protected Area (MPA) Targets: How the Push for Quantity Over Quality Undermines Sustainability and Social Justice," Journal of Environmental Management 124, no. 1 (2013): 137-46, https://doi.org/10.1016/j.jenvman.2013.01.033.

9 Abdul Halik, Marco Verweij, and Achim Schlüter, "How Marine Protected Areas Are Governed : A Cultural Theory Perspective," Sustainability 10, no. 1 (2018): 1-23, https://doi.org/10.3390/su10010252; Novriyanto et al., "Linking Coastal Community Livelihoods to Marine Conservation in Aceh, Indonesia," Oryx 46, no. 4 (2012), https://doi.org/10.1017/S0030605312000622. 
imposing the heaviest criminal sanctions for perpetrators of coral destruction, and handing over full authority over MPAs management to the Marine and Fisheries Ministry.

\section{RESEARCH METHODS}

This article discusses three international legal frameworks and six national legislation related to MPAs in Indonesia. International legal frameworks discussed include the 1982 United Nations Convention on The Law of the Sea (UNCLOS), 1992 Convention on Biological Diversity (CBD), and 1995 Code of Conduct for Responsible Fisheries (CCRF). Meanwhile, the five national legislation analyzed in this paper include the Act 5/1990 concerning Conservation of Living Resources and their Ecosystems, the Act 31/2004 and amendment Act 45/2009 concerning Fisheries, the Act 27/2007 and amendment Act Number 01 / 2014 concerning the Management of Coastal Areas and Small Islands, the Act 32/2014 on Marine Affairs, and the Act 26/2007 concerning Regional Spatial Planning. Specifically, this paper analyzes progress, problems, and solutions in managing marine protected areas in Indonesia. Furthermore, to obtain actual data regarding the progress and problems in managing MPAs, this study also conducted interviews. This interview used a semi-structured questionnaire involving thirteen participants, seven staff from the Ministry of Marine Affairs and Fisheries, and six staff from the Ministry of Environment and Forestry. All findings were interpreted, analyzed, and presented qualitatively.

\section{ANALYSIS AND DISCUSSION}

\section{International Legal Framework for Marine Conservation}

The development of laws and policies on marine protected areas in Indonesia is closely related to the nation's obligations or commitments to adopt international legal provisions. ${ }^{10}$ Indonesia's government has currently adopted several standard principles in the international legal framework related to marine conservation. The standard principles adopted are harmonized with existing laws and policies in Indonesia. The sources of international law discussed in this paper are limited to legal frameworks closely related to Indonesian MPAs and fisheries' development.

Several international legal frameworks that encourage the development of marine protected areas in Indonesia include, first, the United Nations Convention on the Law of the Sea (UNCLOS) 1982. The Indonesian government officially ratified UNCLOS through Act 17/1985 concerning the Ratification of the United Nations Convention on The Law of The Sea. ${ }^{11}$ Article 61 of the 1982 UNCLOS mandates the Coastal States to take the necessary steps to conserve and protect living resources to prevent overfishing of resources in the Exclusive Economic Zone of each Coastal State based on the best available information. Article 63 of the $1982 \mathrm{UN}$ CLOS asks each Coastal State to cooperate with international organizations, both at the subregional, regional, and global levels, in ensuring the continuity or conservation of marine biological resources in its territory. Besides, in article 62, the 1982 UNCLOS asks the Coastal States to properly notify conservation and management regulations. This Convention also recognizes the general obligation for all States to protect and preserve the marine environment. In article 194, the 1982 UNCLOS states that the Coastal States must take all necessary steps to protect

10 Alan T White et al., "Marine Protected Areas in the Coral Triangle : Progress, Issues, and Options," Coastal Management 42, no. 2 (2014): 37-41, https://doi.org/10.1080/08920753.2014.878177.

11 Usmawadi, "Implementation of the UNCLOS 1982 in Utilization of Highly Migratory Species By Indonesia," Sriwijaya Law Review 4, no. 1 (2020): 124-35, https://doi.org/10.28946/slrev.Vol4.Iss2. 
and preserve rare or fragile ecosystems and threatened or endangered species and other marine life forms. This Convention has well defined the state's duty to protect living resources and the environment and the extent to which the Coastal States can implement them without disturbing other States' rights and interests.

Second, the United Nations Convention on Biological Diversity (CBD) 1992. This Convention's main objective is to achieve conservation, sustainable use, and equitable sharing of the benefits arising from the use of biological resources. Overall, this Convention aims to promote action activities that lead to sustainable use efforts. Indonesia ratified the 1992 CBD through the Act 5/1994 concerning the United Nations Convention on Biological Diversity's ratification. ${ }^{12}$ In article 3, the CBD asks States parties to the Convention to ensure that activities carried out within its jurisdiction or control will not damage the environment of other countries or areas outside the boundaries of their national jurisdiction. Article 6 of this Convention requests that each state, with its particular conditions and capacities, shall develop a national strategy, plan, or program for the conservation and sustainable use of biological diversity or adapt existing strategies, plans, or programs. Also, every country should integrate the conservation and sustainable use of biological diversity into related sectoral or cross-sectoral plans, programs, and policies. Then, article 8 of the CBD mandates each country to develop a system of conservation areas or areas that require special handling to conserve biodiversity. Therefore, each country must develop guidelines for the settlement, establishment, and management of conservation areas or areas that require extraordinary measures for the conservation of biodiversity. This Convention also obliges each country to create the conditions necessary for the harmony between current uses and the conservation of biological diversity and its components' sustainable use. Conservation is a critical approach that every Coastal State must adopt. However, MPAs are not stated in writing, so that UNCLOS is a global regulation that does not directly affect marine protected area policies ${ }^{13}$ in Indonesia.

Third, Code of Conduct for Responsible Fisheries (CCRF) 1995. To avoid continuous overfishing, the United Nations had established the Code of Conduct for Responsible Fisheries (CCRF) in 1995. This code of conduct sets out the principles of international standards of behaviour regarding responsible practices in fishing. ${ }^{14}$ Although voluntary, the provisions in this code of conduct are global, aimed at the state, government, and non-government and all private fisheries parties, both members and non-members of the United Nations. ${ }^{15}$ The CCRF was adopted on 31 October 1995 and is in the soft law category. Thus, the Government of Indonesia does not need to establish special regulations in ratifying the CCRF. All of the rules in the CCRF have the aim of assisting Coastal Countries in the world in developing fisheries based on

12 Laely Nurhidayah, "Marine Biodiversity Laws in Indonesia and Australia: Mapping Similarities and Differences," Asia Pacific Journal of Environmental Law 21, no. 1 (2018): 50-76, https://doi.org/https://doi.org/10.4337/apjel.2018.01.03.

13 Hai Dang Vu, "Towards A Network of Marine Protected Areas A Network of Marine Protected Areas in the South China Sea: Legal and Political Perspectives" (Dalhousie University, 2013).

14 Mimi E. Lam and Tony J. Pitcher, "The Ethical Dimensions of Fisheries," Current Opinion in Environmental Sustainability 4, no. 3 (2012): 364-73, https://doi.org/10.1016/j.cosust.2012.06.008.

15 Marta Coll et al., "Sustainability Implications of Honouring the Code of Conduct for Responsible Fisheries," Global Environmental Change 23, no. 1 (2013): 157-66, https://doi.org/10.1016/j.gloenvcha.2012.10.017. 
sustainable use of fishery resources. The CCRF explains how fisheries should be regulated responsibly and how to implement fisheries activities under each country's national regulations.

Article 6 of this code of conduct regulates that fish resource users must take conservation actions on marine ecosystems. The right to fishing must also pay attention to the obligation to carry out marine resource conservation and management effectively. Article 6.2 of this code of conduct states that fisheries management must maintain the quality, diversity, and availability of fish resources for present and future generations. Management measures are concerned with the conservation of the fish that are the target of fishing and other species that occupy the same ecosystem and other fish that depend on the target fish's presence. Article 7.5 of the code of conduct asks every country involved in marine fishing to adopt a precautionary principle or approach in the conservation, management, and sustainable use of fish resources following the best information available. However, this lack of scientific information is not an excuse for delaying conservation measures for target species. In Article 6.8 of this code of conduct, all types of habitat essential for fisheries, such as wetlands, mangroves, coral reefs, fish rearing, and spawning grounds, must be protected and rehabilitated. Fisheries managers must take necessary steps to protect these habitats from destruction, degradation, pollution, and other impacts caused by human activities, which can reduce fish resources' health. Also, Article 6.9 of this code of conduct asks every country to integrate the interests of capture fisheries, including the need for conservation of fishery resources, in an integrated coastal area management plan.

\section{National Legislations Related to Indonesia's Marine Protected Areas}

The establishment of marine protected areas requires legislation as a legal basis for litigation if a prohibited activity takes place. Therefore, MPAs personnel in Indonesia needs to understand the legislation relevant to its management. National legal frameworks are an essential tool in the development of MPA in Indonesia. ${ }^{16}$ In the current Indonesian legal regime, there are at least four pieces of legislation related to MPA.

The first legislation is the Act 5/1990 Concerning Conservation of Living Resources and Their Ecosystems. Conservation of living resources and their ecosystems aims to preserve living resources and the balance of ecosystems to support better efforts to improve people's welfare and human life quality. Related to protected areas, article 1 (9) of this Act defines a natural reserve is an area with specific characteristics, which have the primary function as an area of preservation of plant and animal diversity and their ecosystems that also function as areas of life support systems. Then, the nature conservation area consists of a national park, a grand forest park, and a nature park. A person can carry out various activities in a nature conservation area, including research, education, and nature tourism, without reducing its primary function. The national park area management is carried out through a zoning system consisting of a core zone, a utilization zone, and other zones. Article 31 of this legislation prohibits anyone from carrying out activities that alter the park's core zones' integrity. The conservation area in this legislation covers both land and marine areas.

16 Marion Glaser et al., "Whose Sustainability? Top-Down Participation and Emergent Rules in Marine Protected Area Management in Indonesia," Marine Policy 34, no. $6 \quad$ (2010): 1215-25, https://doi.org/10.1016/j.marpol.2010.04.006. 
The second legislation is the Act 31/2004 and amendment Act 45/2009 Concerning Fisheries. Article 13 of the Act Number 31/2004 defines that the management of fish resources is implemented to conserve ecosystems, preserve fish species, and preserve fish genetics. Then, article 7(1) of Act 45/2009 explicitly states marine protected areas, namely protected water areas, managed with a zoning system, to achieve sustainable fish resources and the environment. These legislations prohibit the capture or cultivation of fish in destructive ways, such as using chemicals, biological substances, explosives, or other means that endanger the sustainability of fish resources and the environment in fisheries management areas. These legislations also prohibit acts that result in pollution, breeding genetically modified fish, and using drugs that can endanger fish resources, the environment of fish resources, and human health. MPA management in both of these legislations is more focused on sustainable fisheries.

The third legislation is the Act 27/2007 and amendment Act Number 01/2014 Concerning the Management of Coastal Areas and Small Islands. Article 1 (20) of Act 1/2014 states that conservation areas on the coast and small islands are coastal areas and small islands with specific characteristics protected to realize sustainable management of coastal areas and small islands. The allocation of space in the conservation area is part of the zoning plan for coastal areas and small islands considering harmony and balance with the carrying capacity of the ecosystem, integration of various types of resources, and the obligation to allocate community space and access in the use of coastal areas and small islands that have social and economic functions. Meanwhile, article 28 of Act 27/2007 states that the coastal areas and small islands' conservation efforts are to conserve coastal ecosystems and small islands, protect the migration routes of fish and other marine biotas, and protect traditional cultural sites. The categories of coastal conservation areas and small islands include coastal reserves, small island reserves, coastal parks, and small island parks.

Then, the fourth is the Act 32/2014 on Marine Affairs. Article 1 (10) of this legislation mandates to protect the marine environment with systematic and integrated efforts to conserve marine resources and prevent environmental pollution and damage to the sea. These efforts include the conservation of the sea, control of marine pollution, management of marine disasters, pollution prevention, mitigation, and damage and disasters. Article 43 (1) of this Act states that marine spatial plans and zoning are the basis for establishing MPAs. Marine Conservation Efforts through MPAs are performed to protect, conserve, and utilize marine resources, including ecosystems, species, and genetics, to ensure their existence, availability, and sustainability while maintaining and enhancing marine resources diversity. Marine conservation efforts include the protection and preservation of marine biota which have a range and remote area such as reptiles (various types of sea turtles) and Marine mammals (whales and dugongs) as well as in the context of protecting cultural sites and geomorphological features of the sea such as sea mountains. Based on article 51, this Act states that the government can establish marine conservation policies as an integral part of protecting the marine environment. Under their authority, the Central and Local Governments have management rights over MPAs as part of the implementation of marine environmental protection policies. The marine conservation policy must be performed across sectors and regions to support the marine environment's protection. Each sector that performs development in territorial waters and jurisdictions must pay attention to protected areas. 


\section{Progress and Control of the Establishment of Marine Protected Areas in Indonesia}

In 1975, the Republic of Indonesia Government established the first MPAs, namely Bunaken Marine National Park in North Sulawesi province and Kepulauan Seribu Marine National Park in Jakarta. ${ }^{17}$ Nevertheless, until the early 1980 s, the MPAs concept was still only a 'paper tiger' due to poor law enforcement and ineffective governance. ${ }^{18}$ In theory, the first effort to establish MPAs were reasonable, but not in practice. ${ }^{19}$

The MPAs concept began to be taken into account in 1980 when the overfishing, massive exploitation of marine resources, and food crises in several parts of the globe resulted from flooding. ${ }^{20}$ In 1982, the Law of the Sea (LOS) Convention provided a legal basis at the international conventions level, followed by the 1992 Convention on Biological Diversity (CBD). The United Nations considers that the CBD establishment in 1992 was substantial to protect biodiversity and prevent it from damage. The establishment of marine protected areas is one method for performing the CBD mandate. ${ }^{21}$ Currently, global marine protected areas' total area reaches 27 million $\mathrm{km} 2$, representing $7.4 \%$ of the world's oceans. ${ }^{22}$

The term marine protected area adopted by stakeholders and government agencies describes conservation areas in coastal and marine areas. There are various terms for Indonesia's MPAs. These terms are followed by the agencies that administer zones. There are three leading agencies in charge of managing MPAs in Indonesia. These agencies are the Marine Affairs and Fisheries Ministry, Environment and Forestry Ministry, and Local Governments (Provincial and City/Regency).

The Environment and Forestry Ministry mention two types of 'natural protected areas' in article 14 of the Act 5/1990 on Conservation of Biological Resources and Ecosystems. These are sustainable areas and reserve areas. The nature reserve area consists of wildlife reserves and a strict nature reserve area. Subsequently, article 4 of the Government Regulation 28/ 2011 on Management of the Nature Reserve and Nature Conservation Area, divides the nature reserve area into two types: nature reserves and wildlife reserves. Meanwhile, nature conservation areas include national parks, grand forest parks, and nature tourism parks.

The Marine Affairs and Fisheries Ministry calls the marine protected area as an 'area of fisheries sanctuary,' referring to the Government Regulation 60/2007 on Fish Resources Conservation. Then, the local government uses the term locally marine managed areas to apply to marine protected areas. These terms follow the definition of marine protected areas from the International Union for Conservation of Nature (IUCN). After the promulgation of the Act 5/1994 on Ratification of Convention on Biological Diversity, the number of marine protected

17 Tomas Tomascik, The Ecology of the Indonesian Seas, 2nd ed (Oxford: Oxford University Press, 1997).

18 Dirhamsyah, "Setbacks in the Development of Marine Protected Areas in Indonesia," Australian Journal of Maritime \& Ocean Affairs 8, no. 2 (2016): 87-100, https://doi.org/10.1080/18366503.2016.1187781.

19 N. Alder, N.A. Sloan, and H. Uktolseya, "Advances in Marine Protected Area Management in Indonesia: 1988-1993," Ocean and Coastal Management 25, no. 1 (1994): 63-75.

20 U. Thara Srinivasan et al., "Food Security Implications of Global Marine Catch Losses Due to Overfishing," Journal of Bioeconomics 12, no. 3 (2010): 183-200.

21 Tundi S. Agardy, Marine Protected Areas and Ocean Conservation, $1^{\text {st }}$ ed. (California: Academic Press, 1997), p. 45; Daniel C. Dunn et al., "The Convention on Biological Diversity's Ecologically or Biologically Significant Areas: Origins, Development, and Current Status," Marine Policy 49, no. 1 (2014): 137-45.

22 UNEP-WCMC, IUCN, and NGS, “Global Coverage," Protected Planet, 2020. (accessed 20 August 2020). 
areas increased dramatically. In 2010, Indonesia only had 82 MPAs, with a total area of 13.9 million hectares. ${ }^{23}$ It can be seen in the table 1 that in 2019 , the number of Indonesia's marine protected areas had increased dramatically to 177 areas, with a total area of 20.87 million hectares.

Table 1, Status of Indonesia's Marine Protected Areas 2019

\begin{tabular}{llcc}
\hline \multicolumn{1}{c}{$\begin{array}{c}\text { Government } \\
\text { Institutions }\end{array}$} & \multicolumn{1}{c}{ Types of Areas } & Unit & Extent (Hectare) \\
\hline \multirow{2}{*}{$\begin{array}{llc}\text { Marine Affairs and Fisheries } \\
\text { Ministry }\end{array}$} & Aquatic National Park & 1 & $3,355,352.82$ \\
& Aquatic Sanctuary & 3 & 445,630 \\
& Aquatic Tourism Park & 6 & $1,541,040$ \\
& Total & $\mathbf{1 0}$ & $\mathbf{5 , 3 4 2 , 0 2 3 . 0 2}$ \\
$\begin{array}{l}\text { Local Government (Provin- } \\
\text { cial Government) }\end{array}$ & Locally Managed Marine Areas & 137 & $10,901,101.76$ \\
& Total & $\mathbf{1 4 7}$ & $\mathbf{1 0 , 9 0 1 , 1 0 1 . 7 6}$ \\
Environment and Forestry & Marine National Park & 7 & $4,043,541.30$ \\
Ministry & Marine Tourism Park & 14 & 491,248 \\
& Wildlife Reserve & 4 & 5,400 \\
& Nature Reserve & 7 & 91,820 \\
& Total & $\mathbf{3 0}$ & $\mathbf{4 . 6 3 2 . 0 0 9 , 3 0}$ \\
& TOTAL NUMBER & $\mathbf{1 7 7}$ & $\mathbf{2 0 . 8 7 5 . 1 3 4 , 0 8}$ \\
\hline
\end{tabular}

Source: Indonesian Marine Affairs and Fisheries Ministry, 2019

Furthermore, other driving factors cause an increase in the number of Indonesia's marine protected areas. The first factor was the alteration in the Indonesian regime from autocracy to decentralization. Act Number 32/2004 concerning Local Government has given the mandate to manage marine natural resources to local authorities (provincial and city/county governments).

According to article 18 of this Act, the provincial government has jurisdiction to manage marine resources up to 12 nautical miles from the coastline. In contrast, the county/city governments can manage marine resources up to 4 nautical miles. Suppose the marine area between 2 provinces is less than twenty-four nautical miles. In that case, jurisdiction to manage resources in the marine area is shared equally or measured according to the area's principle of diameter between the two provinces. County/city governments get one-third of the territorial authority of the province. This Act has provided a legal basis for the government, stakeholders, and the community to develop many marine protected areas in Indonesia.

The second factor was the increasing awareness of the government in sustainably managing marine resources. It has proven with the approval of the marine protected areas concept in the government's official policy. The marine protected area draft was established in state policy outlines in 1998. ${ }^{24}$ According to this document, the marine and coastal areas' management must pay attention to the natural resources and environment. The commitment of the government to developing marine protected areas continues. The government declared a target of developing

23 MMAF, Information on Indonesia's Marine Protected Areas 2013, 1st ed. (Jakarta: Indonesian Ministry of Marine Affairs and Fisheries, 2013). (accessed 20 August 2020).

24 MMAF, "The History of Indonesian Marine Protected Area (MPA) Development," 2012. (accessed 20 August 2020). 
10 million hectares of marine protected areas until 2010, at the 2006 meeting of the Convention on Biological Diversity. ${ }^{25}$ Subsequently, at the 2009 World Ocean Conference, the government targeted to expand the marine protected areas to twenty million hectares until 2020.

\section{Current Problems in the Management of Marine Protected Areas}

Currently, there are four problems in managing marine protected areas in Indonesia. First, the conflict between management permit and concession permit. The Act 1/2014 on Management of Coastal Areas and Small Islands contains provisions for management permits. A management permit is a license granted to conduct activities to utilize marine, coastal, and small island resources. Article 9 (1) of this legislation requires that every marine tourism entrepreneur conducting business in marine and coastal areas must have a management permit. Meanwhile, Article 8 of Government Regulation 36/2010 concerning Exploitation of Nature Tourism in Wildlife Reserves, National Parks, Grand Forest Parks, and Nature Tourism Parks requires aquatic tourism entrepreneurs to obtain a concession permit before starting their business. This government regulation aims to increase the utilization of uniqueness, natural beauty, and diversity of wild animals and plant species found in wildlife reserves, national parks, grand forest parks, and natural tourism parks. The exploitation of marine tourism is also possible located in coastal areas or MPAs. The conclusion is that entrepreneurs have to take care of two permits from two institutions, ${ }^{26}$ namely a management permit based on The Act 1/2014 and a concession license based on Government Regulation 36/2010. These problems have the potential to create high costs and too much bureaucracy.

Second, conflicts between regional spatial plans and zoning plans for marine, coastal areas, and small islands. Article 24(1) of Act 26/2007 concerning Regional Spatial Planning states that a Local Government Regulation stipulates a detailed spatial plan. The regional spatial planning includes land space, marine space, and air space. Meanwhile, Article 9(5) of Act $1 / 2014$ states that zoning plans for marine, coastal, and small island areas are also regulated through local government regulations. Regional spatial planning and zoning plans for marine, coastal, and small islands regulate different land management regimes and marine management matters. Therefore, at the technical level, two different local government regulations must also be issued. The period for regional spatial planning or zoning plans for marine, coastal, and small islands is valid for twenty years. Furthermore, article 9(2) of The Act 1/2014 states that zoning plans for marine, coastal, and small islands must be harmonized and balanced with provincial or district/city spatial plans. This provision emphasizes that the two plans should not have to creates two different formats of local government regulations. Creating these two different local government regulations will result in the excessive imposition of the regional budget.

Third, the occurrence of multiple interpretations of distinct penal sanctions against the same crime. Article 84 of Act 31/2004 concerning Fisheries states that cultivating fish using

25 Irfan Yulianto, Tasrif Kartawijaya, and Stuart Campbell, "The Effectiveness of Karimunjawa National Park," in Proceeding of International Symposium on Small Islands and Coral Reefs, ed. Jamaluddin Jompa (Ambon, 2010), 167-78.

26 Rilus A. Kinseng et al., "Marine-Tourism Development on A Small Island in Indonesia: Blessing or Curse?," Asia Pacific Journal of Tourism Research 23, no. 11 (2018): 1062-72, https://doi.org/10.1080/10941665.2018.1515781. 
chemical, biological and explosive substances which can harm and or endanger the sustainability of fish resources and or the environment shall be punished with imprisonment of up to six years and a maximum fine of one billion two hundred million rupiahs. Meanwhile, article 73 of Act 1/2014 stipulates that a person who takes coral reefs in marine protected areas using explosives and poisonous materials, and or other means that damage the coral reef ecosystem, is subject to imprisonment of between two years and ten years and a fine of between two billion and ten billion rupiahs. The question is if someone is fishing with explosives causing damage to the coral reef ecosystem, which legislation is used to prosecute that person? There are different criminal sanctions for crimes between the Fisheries Act and the Coastal Act, resulting in the same damage to coral reefs. This legal uncertainty disturbs the sense of justice in society.

Fourth, institutional conflicts in the management of MPAs. Article 78A of the Act 1/2014 mandates that marine protected areas that have been established through legislation before this Act applies are the authority of the Minister of Marine and Fisheries. The legislation regulates the transfer of marine protected areas from the Ministry of Environment and Forestry (MEF) to the Ministry of Marine Affairs and Fisheries (MMAF). However, the MEF still manages it in practice. A protracted institutional transfer will lead to ineffective and inefficient operations of the organization.

\section{Possible Solutions}

This paper offers possible solutions to solve the problems previously mentioned. The first solution proposed to overcome licensing dualism is synchronizing marine tourism permits in marine protected areas between the Ministry of Marine Affairs and Fisheries and the Ministry of Environment and Forestry. The Act 1/2014 requires aquatic tourism entrepreneurs conducting business in coastal and marine areas to have a management permit. Meanwhile, Government Regulation 36/2010 stated that aquatic nature tourism entrepreneurs must have a concession license before operating their business. It means that marine tourism entrepreneurs have to take care of two different permits. Exploitation permit for marine tourism in wildlife reserves, national parks, grand forest parks, and nature tourism parks, the licensing process is under the Ministry of Environment and Forestry's authority. Meanwhile, marine tourism management permits in marine and coastal areas are under the Ministry of Marine Affairs and Fisheries' authority. This double licensing occurred because, based on Act 1/2014, there was a transfer of management of seven marine national parks from the Ministry of Environment and Forestry to the Ministry of Marine Affairs and Fisheries. Seven marine national parks that have changed their authority from the Ministry of Environment and Forestry to the Ministry of Marine Affairs and Fisheries include Wakatobi Islands marine national park, Bunaken marine national park, Karimunjawa marine national park, Kepulauan Seribu marine national park, Togean Islands marine national park, Teluk Cenderawasih marine national park, and Taka Bonerate marine national park. In practice, currently, this transfer of several marine national park management has not been completed. ${ }^{27}$ These two ministries' licensing mechanism is still valid, so marine tourism entrepreneurs have to take two licenses at these two agencies. In the future, it will be nec-

27 Achmad Sahri et al., "A Critical Review of Marine Mammal Governance and Protection in Indonesia," Marine Policy 117, no. 1 (2020): 1-16, https://doi.org/10.1016/j.marpol.2020.103893. 
essary to affirm that the Ministry of Environment and Forestry is no longer authorized to manage marine tourism in marine protected areas so that the Ministry of Marine Affairs and Fisheries can take over the management authority under the Act 1/2014.

The second solution to resolve conflicts between marine zoning plans and regional spatial plans is to integrate the two plans into local government regulation. The formulation of zoning plans for marine, coastal areas and small islands in Act 1/2014 is equivalent to the regional spatial planning. The regional spatial plan is more concerned with land affairs, while the zoning plan for marine, coastal areas, and small islands are related to spatial in marine waters (lex specialist). The Act 27/2007 concerning the Management of Coastal Areas and Small Islands mandates that marine, coastal and small islands areas should use spatial structures and patterns that already exist in the spatial planning local government regulations. However, in practice, the regional spatial plan and zoning plan for marine, coastal, and small islands are regulated in two different local government regulations. This arrangement is more efficient and effective if set in one local government regulation to burden regional income.

The third solution is to overcome multiple interpretations of criminal sanctions by synchronizing the concept of fisheries crime with the destruction of coral reefs to impose the most massive criminal sanctions. Mangroves, seagrass meadows, and coral reefs are three important ecosystems in marine protected areas. ${ }^{28}$ The coral reef is the essential ecosystem in this area because it is a place for fish and marine life to live and breed. ${ }^{29}$ Apart from a source of benefits from fisheries, coral reefs also provide added value to the tourism industry sector and are also useful as a buffer for coastal areas. The Indonesian archipelago has a coral reef area of 25,000 square kilometres or about ten per cent of the world's total coral reefs. ${ }^{30}$ Unfortunately, the splendour of Indonesia's coral reefs is not well preserved. The data of 2018 from the Indonesian Institute of Sciences' Center for Oceanographic Research reveal that only $6.56 \%$ of Indonesia's coral reefs were considered very good. While $22.96 \%$ is considered acceptable, $34.30 \%$ are poor conditions, and $36.18 \%$ are in the worst condition. Even in the last half-century, the degradation of coral reefs in Indonesia increased from $10 \%$ to $50 \%{ }^{31}$

Observing this damage, the exploitation of environmental resources in marine and coastal areas must be a serious concern. Against this appalling condition, it is necessary to enforce clear laws and regulations in comprehensive marine and coastal resources management. Some of the actions that damage the coral reef ecosystem are fishing using materials or tools that endanger fish resources and the environment, mining and extracting corals, water pollution, and development activities in marine and coastal areas. Due to the rampant destruction of coral reefs, the Act 1/2014 has included convictions for the perpetrators of this destruction. This law's criminal imposition is between two and ten years and a fine between two billion rupiahs and ten billion rupiahs. However, law enforcement against the criminal law of destroying coral

28 Kentaro Honda et al., "Habitat Use by Fishes in Coral Reefs, Seagrass Beds and Mangrove Habitats in the Philippines,” PLoS ONE 8, no. 8 (2013): 1-10, https://doi.org/10.1371/journal.pone.0065735.

29 Fredrik Moberg and Carl Folke, "Ecological Goods and Services of Coral Reef Ecosystems," Ecological Economics 29, no. 2 (1999): 215-33, https://doi.org/10.1016/S0921-8009(99)00009-9.

30 Indonesia Climate Change Trust Funds, "Nine Years to Commemorate World Coral Reef Day, What Are the Conditions in Indonesia?," 2020. (accessed 22 August 2020).

31 LIPI Oceanography Research Center, “Indonesian Coral Reef Damage Reaches 35.15 Percent," 2017. (accessed 24 August 2020). 
reefs can be hampered because of the inconsistency in terms of the punishment for damaging ecosystems in marine and coastal areas. It is because the Act 31/2004 concerning Fisheries regulates different criminal sanctions with the Act 1/2014 concerning Management of Coastal Areas and Small Islands. The imposition of criminal sanctions in Act 31/2004 is lighter than the Act $1 / 2014$, namely a maximum prison sentence of six years and a maximum fine of one billion two hundred million rupiahs. The provisions of the Act on Fisheries that are not synchronous with the Act on Coastal Management are the norms of catching or cultivating fish that endanger the sustainability of fish resources and the environment. The environment referred to in the fisheries legislation includes coral reefs and other marine ecosystems. The destruction of coral reefs regulated in coastal legislation has the same object substance as fishing acts that damage the environment as regulated in fisheries legislation. However, the two legislations provide different criminal sanctions for the two crimes with the same environmental impact. If someone catches fish with an explosive that causes damage to the coral reef ecosystem, which legislation will punish that person? There is a legal loophole, where the perpetrators of destroying coral reefs can argue that they carry out fishing activities, hoping that they will be punished under fisheries legislation because the criminal sanctions are lighter than coastal legislation.

Therefore, if there is a fishery crime that causes damage to coral reefs, the judge who hears the case must make a legal breakthrough by harmonizing the concept of fisheries crime with the destruction of coral reefs massive criminal sanction. Judges can use a legal principle, namely lex posteriori derogat legi priori or the latest law overriding the old law. Fisheries legislation was enacted in 2004, and the most recent change was in 2009, while coastal legislation was promulgated in 2007, and the most recent amendment was in 2014. Based on this legal argument, the imposition of criminal sanctions should refer to coastal legislation with a more deterrent effect so that fisheries activities do not damage coral reef ecosystems.

The fourth problem is the transfer of full authority over the management of seven marine protected areas to the Ministry of Marine Affairs and Fisheries. Promulgation of the Act 1/2014 concerning amendments to Act 27/2007 concerning the Management of Coastal Areas and Small Islands impacts the institutional management of MPAs. The impact of the enactment of the Act 1/2014 is that the entire management of the seven marine protected areas falls under the authority of the Minister of Marine Affairs and Fisheries. In the explanation part of the Act 1/2014 states that the MPAs category, which is under the authority of the Ministry of Marine Affairs and Fisheries, includes nature reserves and nature conservation areas in the form of marine national parks, marine wildlife reserves, marine reserves, marine tourism parks, and marine reserves. Based on this legislation, the transfer of the seven marine protected areas' management should be implemented immediately. However, currently, all seven marine and national parks are still managed by the Ministry of Environment and Forestry through the Directorate General of Natural Resources and Ecosystem Conservation. The Ministry of Environment and Forestry argues that their management of the seven marine protected areas has a legal basis in the Act 5/1990 concerning the Conservation of Living Natural Resources and their Ecosystems. The tug-of-war of institutional interests in managing marine protected areas will result in ineffectiveness in its management. Therefore, it is essential to immediately transfer the management of marine national parks from the Ministry of Environment and Forestry to the Ministry of Marine Affairs and Fisheries under the Act 1/2014. The transfer of management institutions 
must also consider the readiness of facilities and human resources from the Ministry of Marine Affairs and Fisheries.

\section{CONCLUSION}

This paper analyzes three international provisions adopted by Indonesia relating to marine and fisheries conservation. Two of them are in the form of binding international law, namely UNCLOS 1982 and CBD 1992. Meanwhile, the CCRF is a non-binding regulation related to fisheries and marine conservation. The four primary legislation that affects the development of MPAs in Indonesia includes Legislation on Concerning Conservation of Living Resources and Their Ecosystems, Legislation on Fisheries, Legislation concerning Management of Coastal Areas, and Small Islands, and Legislation concerning Marine Affairs.

Establishing marine protected areas in Indonesia has now reached the desired target of 20 million hectares. This progress stems from two main factors. First, the former Local Government Act (Act 32/2004) has changed the marine and coastal management regime in Indonesia from autocracy to decentralized. Secondly was the increasing commitment of the government in sustainably managing natural resources.

However, despite achieving these targets, there are four problems related to the management of MPAs in Indonesia. These problems include the dualism of marine tourism licensing management, conflicts of zoning for marine areas and regional spatial plans, the occurrence of multiple interpretations of the imposition of different penal sanctions against the same crime, and overlapping jurisdictions of government agencies in managing MPAs. To resolve these problems, the solutions offered include synchronizing marine tourism permits, integrate the zoning plans and spatial plans into one local government regulation, impose the most massive criminal sanctions for perpetrators of coral destruction, and the transfer of full authority over the management of marine protected areas to the Ministry of Marine Affairs and Fisheries.

\section{ACKNOWLEDGEMENTS}

This article is part of a doctoral thesis research at the Institute of the Law of the Sea, College of Ocean Law and Policy, National Taiwan Ocean University, Taiwan.

\section{REFERENCES}

Abelson, A., P. A. Nelson, G. J. Edgar, N. Shashar, D. C. Reed, J. Belmaker, G. Krause, et al. "Expanding Marine Protected Areas to Include Degraded Coral Reefs." Conservation Biology 30, no. 6 (2016): 1182-91. https://doi.org/10.1111/cobi.12722.

Agardy, Tundi S. Marine Protected Areas and Ocean Conservation. 1st ed. California: Academic Press, 1997.

Alder, N., N.A. Sloan, and H. Uktolseya. "Advances in Marine Protected Area Management in Indonesia: 1988-1993.” Ocean and Coastal Management 25, no. 1 (1994): 63-75.

Brotosusilo, Agus, I. Wayan Agus Apriana, Afrizal Agung Satria, and Trisasono Jokopitoyo. "Littoral and Coastal Management in Supporting Maritime Security for Realizing Indonesia as World Maritime Axis." IOP Conference Series: Earth and Environmental Science 30, no. 1 (2016).

Center, LIPI Oceanography Research. "Indonesian Coral Reef Damage Reaches 35.15 Percent," 2017.

Coll, Marta, Simone Libralato, Tony J. Pitcher, Cosimo Solidoro, and Sergi Tudela. 
"Sustainability Implications of Honouring the Code of Conduct for Responsible Fisheries." Global Environmental Change 23, no. 1 (2013): 157-66. https://doi.org/10.1016/j.gloenvcha.2012.10.017.

Dirhamsyah. "Setbacks in the Development of Marine Protected Areas in Indonesia." Australian Journal of Maritime \& Ocean Affairs 8, no. 2 (2016): 87-100. https://doi.org/10.1080/18366503.2016.1187781.

Dunn, Daniel C., Jeff Ardron, Nicholas Bax, Patricio Bernal, Jesse Cleary, Ian Cresswell, Ben Donnelly, et al. "The Convention on Biological Diversity's Ecologically or Biologically Significant Areas: Origins, Development, and Current Status." Marine Policy 49, no. 1 (2014): 137-45.

Edinger, Evan N., Jamaluddìn Jompa, Gino V. Limmon, Wisnu Widjatmoko, and Michael J. Risk. "Reef Degradation and Coral Biodiversity in Indonesia: Effects of Land-Based Pollution, Destructive Fishing Practices and Changes Over Time." Marine Pollution Bulletin 36, no. 8 (1998): 617-30.

Ferrol-Schulte, Daniella, Philipp Gorris, Wasistini Baitoningsih, Dedi S. Adhuri, and Sebastian C.A. Ferse. "Coastal Livelihood Vulnerability to Marine Resource Degradation: A Review of the Indonesian National Coastal and Marine Policy Framework." Marine Policy 52, no. 1 (2015): 163-71.

Fisheries, Ministry of Marine Affairs and. "Annual Report of the Ministry of Marine Affairs and Fisheries Republic of Indonesia 2017." Jakarta, 2017.

Funds, Indonesia Climate Change Trust. "Nine Years to Commemorate World Coral Reef Day, What Are the Conditions in Indonesia?," 2020.

Glaser, Marion, Wasistini Baitoningsih, Sebastian C.A. Ferse, Muhammad Neil, and Rio Deswandi. "Whose Sustainability? Top-Down Participation and Emergent Rules in Marine Protected Area Management in Indonesia." Marine Policy 34, no. 6 (2010): 121525. https://doi.org/10.1016/j.marpol.2010.04.006.

Halik, Abdul, Marco Verweij, and Achim Schlüter. "How Marine Protected Areas Are Governed: A Cultural Theory Perspective." Sustainability 10, no. 1 (2018): 1-23. https://doi.org/10.3390/su10010252.

Hamdani, Baso. "Threats, Challenges and Opportunities to Marine Protected Areas in the Coral Triangle Area: A Case Study of Indonesia Sea.” World Maritime university, 2018.

Honda, Kentaro, Yohei Nakamura, Masahiro Nakaoka, Wilfredo H. Uy, and Miguel D. Fortes. "Habitat Use by Fishes in Coral Reefs, Seagrass Beds and Mangrove Habitats in the Philippines." $\quad P L O S \quad O N E \quad 8, \quad$ no. $8 \quad$ (2013): $1-10$. https://doi.org/10.1371/journal.pone.0065735.

Kinseng, Rilus A., Fredian Tonny Nasdian, Anna Fatchiya, Amir Mahmud, and Richard J. Stanford. "Marine-Tourism Development on A Small Island in Indonesia: Blessing or Curse?" Asia Pacific Journal of Tourism Research 23, no. 11 (2018): 1062-72. https://doi.org/10.1080/10941665.2018.1515781.

Lam, Mimi E., and Tony J. Pitcher. "The Ethical Dimensions of Fisheries." Current Opinion in $\begin{array}{lllll}\text { Environmental Sustainability } 4, & \text { no. } 364-73 .\end{array}$ https://doi.org/10.1016/j.cosust.2012.06.008.

Magris, Rafael A., Robert L. Pressey, Morena Mills, Daniele A. Vila-Nova, and Sergio Floeter. "Integrated Conservation Planning for Coral Reefs: Designing Conservation Zones for Multiple Conservation Objectives in Spatial Prioritisation." Global Ecology and Conservation 11, no. 1 (2017): 53-68. https://doi.org/10.1016/j.gecco.2017.05.002.

MMAF. Information on Indonesia's Marine Protected Areas 2013. 1st ed. Jakarta: Indonesian Ministry of Marine Affairs and Fisheries, 2013. . "The History of Indonesian Marine Protected Area (MPA) Development," 2012. 
Moberg, Fredrik, and Carl Folke. "Ecological Goods and Services of Coral Reef Ecosystems." Ecological Economics 29, no. 2 (1999): 215-33. https://doi.org/10.1016/S09218009(99)00009-9.

Novriyanto, Joni T Wibowo, Wiwin Iskandar, Gail Campbell, Matthew Linkie, Joni T Wibowo, Wiwin Iskandar, Gail Campbell, and Matthew Linkie. "Linking Coastal Community Livelihoods to Marine Conservation in Aceh, Indonesia." Oryx 46, no. 4 (2012). https://doi.org/10.1017/S0030605312000622.

Nurhidayah, Laely. "Marine Biodiversity Laws in Indonesia and Australia: Mapping Similarities and Differences." Asia Pacific Journal of Environmental Law 21, no. 1 (2018): 50-76. https://doi.org/https://doi.org/10.4337/apjel.2018.01.03.

Sahri, Achmad, Putu Liza Kusuma Mustika, Hadi Yoga Dewanto, and Albertinka J. Murk. "A Critical Review of Marine Mammal Governance and Protection in Indonesia." Marine Policy 117, no. 1 (2020): 1-16. https://doi.org/10.1016/j.marpol.2020.103893.

Santo, Elizabeth M. De. "Missing Marine Protected Area (MPA) Targets: How the Push for Quantity Over Quality Undermines Sustainability and Social Justice.” Journal of Environmental Management 124, no. 1 (2013): 137-46. https://doi.org/10.1016/j.jenvman.2013.01.033.

Srinivasan, U. Thara, William W.L. Cheung, Reg Watson, and U. Rashid Sumaila. "Food Security Implications of Global Marine Catch Losses Due to Overfishing." Journal of Bioeconomics 12, no. 3 (2010): 183-200.

Statistics, Central Bureau of. "Statistics of Marine and Coastal Resources 2018." Jakarta, 2018.

Tomascik, Tomas. The Ecology of the Indonesian Seas. 2nd ed. Oxford: Oxford University Press, 1997.

UNEP-WCMC, IUCN, and NGS. “Global Coverage.” Protected Planet, 2020.

Usmawadi. "Implementation of the UNCLOS 1982 in Utilization of Highly Migratory Species By Indonesia." Sriwijaya Law Review 4, no. 1 (2020): 124-35. https://doi.org/10.28946/slrev.Vol4.Iss2.

Vu, Hai Dang. "Towards A Network of Marine Protected Areas A Network of Marine Protected Areas in the South China Sea: Legal and Political Perspectives." Dalhousie University, 2013.

White, Alan T, Porfirio M Aliño, Annick Cros, Ahmad Fatan, Alison L Green, Shwu Jiau Teoh, Nate Peterson, et al. "Marine Protected Areas in the Coral Triangle: Progress, Issues, and Options." Coastal Management 42, no. 2 (2014): 37-41. https://doi.org/10.1080/08920753.2014.878177.

Yulianto, Irfan, Tasrif Kartawijaya, and Stuart Campbell. "The Effectiveness of Karimunjawa National Park." In Proceeding of International Symposium on Small Islands and Coral Reefs, edited by Jamaluddin Jompa, 167-78. Ambon, 2010. 